THURSDAY, JULY 27, I893.

THE ROTHAMSTED JUBILEE.

$\mathrm{O}$ Saturday next a large gathering of scientific men will assemble in the village of Harpenden to do honour to two investigators who have just completed fifty years of joint labour.

The occasion is unique. It can have happened but seldom that two men have continued their joint scientific investigations for a period like the present; but there are other circumstances, apart from this, which mark the event about to be celebrated as one of exceptional interest. The Rothamsted agricultural experiments are indeed a piece of work of which England may well be proud. They form a splendid example of what is sometimes accomplished amongst us by purely individual effort. The extensive series of costly experiments, carried out on a large scale both in the field and in the laboratory, and with results of national importance, has been maintained for more than fifty years at the sole expense of one man. Nor is this all. Sir J. B. Lawes has made provision for the continuance of these investigations. The laboratory and the experimental fields, with $£ 100,000$, have been placed in the hands of trustees, and the future management of the investigations has been entrusted to a committee, the members of which are elected by various scientific societies.

But it is not only as a striking example of individual zeal and munificence that the Rothamsted agricultural station is remarkable, it is equally so if we regard the character of the work performed. Many of the most important problems connected with agriculture can only be satisfactorily studied by actual experiments in the field; such experiments require to be carried out on a large scale and continued for many years. Boussingault was, we believe, the first who sought to ascertain the chemical statistics of agriculture by a quantitative examination of the actual crops of the farm, and by a study of the constituents of soil, of manure, and of rain-water-the various factors which determine the amount of the harvest. But if the work of Boussingault stands first in order of time, the work of Lawes and Gilbert at Rothamsted immediately follows it, and has been continued for such a much longer series of years, and developed in so many new branches of inquiry, that it is to Rothamsted that the agriculturist has long looked for information concerning the fundamental facts of agricultural chemistry.

The field experiments at Rothamsted are peculiar to the place; in very few of the now numerous agricultural stations in foreign countries has systematic work of this kind been attempted; in none has the work been so extensive and so long continued. No less peculiar to Rothamsted has been the laborious investigation into the composition of oxen, sheep, and pigs in various stages of fattening, and into the chemistry of the fattening process. Of the laboratory investigations we may mention the more recent inquiry into the causes and conditions of the production of nitrates in soil, and respecting the quantity of nitric nitrogen in soils of various history, and in drainage and well waters. But we must not here

No. I 239, VOL. 48] attempt an enumeration of published Rothamsted work, which, according to the last report, has furnished the matter for 125 papers.

Rothamsted is by much the oldest of existing agricultural stations. The earliest German experimental station was founded in 1852 , the earliest in the United States in 1875. The first agricultural experiments of Mr. Lawes seems to have been made in 1837 ; in this and the two following years he tried numerous experiments on farm crops grown in pots. His trials in the field commenced in I 840 . In I 843 he was fortunate in securing the services of Dr. J. H. Gilbert, a former pupil of Liebig's, who henceforth took the superintendence of the chemical part of the investigations. Dr. Gilbert has devoted his life to the conduct of the Rothamsted experiments, and the valuable results which have been obtained are largely due to his untiring energy, and to the method and order which his character has impressed upon the work. The jubilee to be celebrated this week is reckoned from the year when Dr. Gilbert began to take a share in the work; the same year also saw the first of the experimental wheat crops sown in Broadbalk Field, which, at the present time, bears its fiftieth successive crop, having grown wheat without intermission during half a century. Numerous honours have been conferred on Messrs. Lawes and Gilbert in the course of their long career. Our Universities have bestowed on them degrees. The Royal Society in 1867 awarded them a royal medal. The Society of Arts has during the current year decided to present them with its Albert Medal. Foreign societies and academies have elected them members of their body. In I $882 \mathrm{Mr}$. Lawes received a baronetcy from the Queen.

The jubilee commemoration of the present week took its rise at a meeting held in the rooms of the Royal Agricultural Society on March I, the Prince of Wales occupying the chair. A committee of distinguished men, with the Duke of Westminster as chairman, and $\mathrm{Mr}$. Ernest Clarke, Secretary to the Royal Agricultural Society, as secretary, was appointed to carry out the scheme. The celebration on Saturday will consist, as the readers of NATURE are already aware, in the unveiling of a granite memorial erected in front of the laboratory; in the presentation of congratulatory addresses to Sir J. B. Lawes and Dr. Gilbert; and in the presentation to Sir J. B. Lawes of his portrait, by Hubert Herkomer, R.A. It is hoped that the Right Hon. Herbert Gardner, M.P., the Minister for Agriculture, will preside.

The laboratory, in front of which the celebration is to take place, is itself a testimony to the appreciation with which the labours of Lawes and Gilbert have been regarded. It is not the laboratory originally employed in the early years of the experiments ; this was a barn which had been fitted up for chemical work, and has long ago been pulled down. The present laboratory was built and presented to Sir J. B. Lawes in 1855 by a number of agriculturists, at a time when agriculture was a more profitable pursuit than it is at present. Since then the needs of the work have grown, and a large storehouse for soil and crop samples has been erected by the side of the new laboratory. 
Of greater interest to most visitors than the laboratory is the old manor of Rothamsted. This charming red brick building dates from 1470 , though, like most old buildings, it has since undergone alteration and enlargement. This manor house has been the home of Sir J. B. Lawes' ancestors since 1623 . The history of the family is remarkable. It was in 1564 that Jacques Wittewronge came to England from Flanders in consequence of the religious persecution then prevailing. The family first resided in Buckinghamshire; they afterwards purchased the manor of Rothamsted. Sir J. B. Lawes is a descendant of this family through the female line.

In the manor house of Rothamsted Sir J. B. Lawes was born in 1814. His whole life has been one of great activity; probably few men have accomplished more work. Though for many years a hard-working man of business, he has always loved a retired country life, and has been rarely seen at public meetings. A keen observer and an untiring experimenter, he has given his whole mind to the problems of agric ilture, while his great practical sagacity has enabled him to grasp at once the real bearing and importance of each new fact. Probably no one has taken a more practical and widereaching view of agricultural questions than Sir J. B. Lawes. When the present century is concluded, the work of Lawes and Gilbert at Rothamsted will be reckoned among the prominent achievements deserving a grateful record.

\section{THE ORIGIN AND DEVELOPMENT OF} MUSIC.

Primitive Music: an Enquiry into the Origin and Development of Music, Songs, Instruments, Dances, and Pantornimes of Savage Races. By Richard Wallaschek. (London: Longmans, Green, and Co., 1893.)

M R. WALLASCHEK has not only compiled with I laborious care what appears to be an exhaustive account of the music of so-called savage races, but has based upon the foundations thus laid an able and interesting discussion on the origin and development of music. It is with the latter rather than the former part of his work that I propose to deal in this notice.

The author is led by his researches to regard rhythm as the primitive and primary constituent of music, while melody was in the primitive state, and has remained, secondary and accessory. Harmony is not to be looked upon as a comparatively recent invention among European races. "As soon as music passes the mere rhythmical stage the lowest races in the scale of man begin to sing in different parts in intervals as well as with a bass accompaniment." The order of development therefore is, first rhythm, and then, possibly coeval one with the other, melody and harmony. With what then is the rhythm of primitive music associated? With the rhythm of the dance. If I understand the author rightly this association is, in his opinion, an invariable one in the origin of music. Now, "in dance-music the idea is to excite the performer and to fatigue him even to exhaustion. The musical dance-chorus is of a social NO. [ 239 , vol. 48 ] character; music keeps the company together and enables them to act simultaneously." I quote here from the author's summary, which is no doubt somewhat condensed and elliptical. One can hardly suppose that "fatigue even to exhaustion " was part of the primary "idea" (understanding by this word aim and object) of the dance. Would it not have been better to say that a part of the "idea" was to test and tax the powers of endurance of the performers? Be this as it may, war, the chase, and sexual passion afford the underlying motives of that emotional excitement which finds its expression in the rhythm of the dance; and thus this rhythm becomes most intimately bound up with practical lifepreserving and life-continuing activities, or, in other words, with activities which are distinctly of naturalselection value. The large share taken by women in the dance and primitive music enables them to contribute not ineffectually towards the success of the tribe in its struggle with other tribes.

"If it be asked whence the sense of rhythm arises, I answer," says the author, "from the general appetite for exercise. That this occurs in rhythmical form is due to sociological as well as psychological conditions. On the one hand there is the social character of primitive music, compelling a number of performers to act in concert. On the other, our perception of time relations involves a process of intellection," and hence an appreciation of time, order, and rhythm. I would suggest that the psychological basis of the "sense of rhythm" might be found in experiences more primitive than any process of intellection-in the organic rhythms of our daily life. We cannot walk nor breathe except to rhythm; and if we watch a little child we shall obtain abundant evidence of rhythmic movements. This I should have placed first ; and then the concerted rhythms of social activities. "Whence," asks Mr. Wallaschek, "does the general desire for exercise a:ise? Mr. Herbert Spencer's theory affords," he replies, "the most valid explanation. It is the surplus vigour in more highly evolved organisms, exceeding what is required for immediate needs, in which play of all kinds takes its rise ; manifesting itself by way of imitation or repetition of all those efforts and exertions which were essential to the maintenance of life (e.g. the war-dance)." In explanation of the term "surplus vigour" the author does well to point out that this is not meant to imply a surplus beyond the needs of the organism at any time of its life, but a temporary surplus beyond its needs in times of unmolested peace and plenty.

While accepting Mr. Spencer's general theory of surplus vigour, Mr. Wallaschek is not prepared to accept the speech-theory of the origin of music, "Whereas Mr. Spencer," he says, "seems to think that musical modulation originates in the modulations of speech, I maintain that it arises directly from the rhythmical impulse." Without presuming to decide between Mr. Herbert Spencer and Mr. Wallaschek, I venture to point out how much depends upon the exact definition of "music" and of "speech." Mr. Walla. schek, as we have seen, regards primitive music as essentially rhythm without necessary association with either melody or harmony. It is a mere tone-rhythm in 